\title{
Partial Characterization of an Acidic Protease from Rhizopus stolonifer RN-11
}

\author{
$\mathrm{Na} \mathrm{Liu}{ }^{*}$ and Liang Huang
}

College of Biological Engineering, Henan University of Technology, Lianhua Street 100, High \& New Tech
Development District, Zhengzhou 450001, China

\begin{abstract}
The present study characterises an acidic protease purified from the Rhizopus stolonifer strain, RN-11. The acidic protease with a $70 \mathrm{kDa}$ molecular weight, was stable within $\mathrm{pH} 2-4$ at temperatures $40-50^{\circ} \mathrm{C}$. The temperature and $\mathrm{pH}$ value conducive to optimal catalytic activity were $\mathrm{pH} 2.5$ and $50^{\circ} \mathrm{C}$, respectively. Treatment with 5 mmol metal ions showed that the acidic protease was activated by $\mathrm{Na}^{+}, \mathrm{K}^{+}, \mathrm{Mn}^{2+}, \mathrm{Cu}^{2+}$ and $\mathrm{Ca}^{2+}$, inhibited by $\mathrm{Zn}^{2+}, \mathrm{Li}^{2+}$ and $\mathrm{Fe}^{2+}$, and unaffected by $\mathrm{Mg}^{2+}$. It was proposed that the studied acidic protease might represent a previously uncharacterised type of acidic protease produced by the Rhizopus stolonifer RN-11 strain.
\end{abstract}

Keywords: Enzyme characteristics, purification, Rhizopuspepsins.

\section{INTRODUCTION}

Acidic proteases degrade proteins in acidic conditions, rendering them useful for medical applications, food processing, and animal feed production [1]. Several studies have isolated acidic proteases from different fungi, including $A s$ pergillus niger [2, 3], Aspergillus oryzae [4-6], Penicillium spp. [7, 8], Mucor pusillus [7, 9], Candida albicans [10], and Rhizopus spp. [11]. Rhizopuspepsins are a family of acidic proteases isolated form the Rhizopus genus [12, 13]. Rhizopuspepsins have been isolated and biochemically characterized in $R$. chinensis [14], R. microsporus [15], R. hangchow [16], $R$. oryzae MTCC 3690 [11], and $R$. oryzae NBRC 4749 [17]. However, few studies concern the characterisation of Rhizopus stolonifer isolates. The present study characterises an acidic protease purified from the Rhizopus stolonifer strain RN-11.

\section{MATERIAL AND METHODS}

Strain screening and culture conditions: The strains used in this study were provided by the Industry Culture Collection Center of Henan University of Technology. Rhizopus stolonifer was activated and grown on seed medium (1:10 (w:v)) with a bran-water ratio, boiled for 30 minutes, and then filtered through four layers of gauze with $0.5 \%$ (w) ammonium sulphate for 48 hours at $30^{\circ} \mathrm{C}$ with gentle agitation. $100 \mu \mathrm{L}$ of filtered fermentation broth was added into sample wells containing separation medium (Czapek medium plus $1 \%$ casein (w), $\mathrm{pH} 3-5$ ) and incubated at $50^{\circ} \mathrm{C}$ overnight. The RN-11 Rhizopus stolonifer strain was selected for its conspicuous acidic protease activity.

*Address correspondence to the author at Henan University of Technology, Zhengzhou 450001, China; Tel: 86-0371-67756253;

Fax: 86-0371-67756253; E-mail: liuna3456@163.com
ITS sequence analysis and morphology: 48 hour cultures grown on seed medium at $30^{\circ} \mathrm{C}$ with gentle agitation were used for Genomic DNA (gDNA) isolation. gDNA was extracted from cultures using the SDS-CTAB method [18]. The primers used for ITS sequence amplification were ITS4 (5'TCCTCCGCTTATTGATATGC-3') and ITS5 (5'GGAAGTAAAAGTCGTAACAAGG-3'). PCR programs were run with a Biometra Tpersonal-48 PCR Thermal Cycler, consisting of an initial denaturation step $\left(95^{\circ} \mathrm{C}\right.$ for 5 minutes) followed by 30 cycles comprising of denaturation $\left(94^{\circ} \mathrm{C}\right.$ for 30 seconds), annealing $\left(55^{\circ} \mathrm{C}\right.$ for 1 minute), extension $\left(72^{\circ} \mathrm{C}\right.$ for 1 minute), and a final extension step $\left(72^{\circ} \mathrm{C}\right.$ for 10 minutes). Fragments were purified from agarose gel using the SanPrep Column DNA Gel Extraction Kit (Sangon Biotech, Shang Hai, China) and entrusted to Life Technologies (Shang Hai, China) for ITS sequencing. Strain morphology was observed and identified using the methods described by Wei [19].

Protein determination: Protein concentration of purified acidic protease was determined with the Bradford method [20].

Purification of acidic protease: The RN-11 strain was inoculated into $100 \mathrm{~mL}$ seed medium and incubated at $30^{\circ} \mathrm{C}$ with gentle agitation for 48 hours. Culture supernatant was diluted to $10^{7} \mathrm{CFU} / \mathrm{mL}$ spore suspension. $1 \mathrm{~mL}$ spore suspension was inoculated into the solid fermentation medium $(15 \mathrm{~g}$ bran, $10.7 \mathrm{~mL}$ water, $0.69 \mathrm{~g}$ sucrose and $1.0 \mathrm{~g}, \mathrm{NaNO}_{3}$, $\mathrm{K}_{2} \mathrm{HPO} 40.042 \mathrm{~g}, \mathrm{pH} 2.5$ ), and incubated at $30^{\circ} \mathrm{C}$ for 72 hours. The crude enzyme solution was extracted from pulverized solid fermentation products with lactic acid buffer (30:1 (v:w) liquid-solid ratio, $\mathrm{pH} 3.0$ ) at $30^{\circ} \mathrm{C}$ for 105 minutes, and centrifuged at $4^{\circ} \mathrm{C}$ with $4200 \mathrm{~g}$. Ammonium sulfate (w) was added to $100 \mathrm{~mL}$ crude enzyme solution to achieve $50 \%$ saturation, thereby removing impure proteins. The enzyme solution was incubated at $4^{\circ} \mathrm{C}$ for 24 hours, centrifuged at $8200 \mathrm{~g}$ for 10 minutes, and then the precipitate 
Table 1. Purification of Proteases from Rhizopus stolonifer RN-11.

\begin{tabular}{|c|c|c|c|c|c|}
\hline Crude enzyme & 80120.00 & 4493.60 & 17.83 & 1.00 & 100 \\
\hline Dialysis & 56773.03 & 104.95 & 540.96 & 30.34 & 70.86 \\
\hline $\begin{array}{c}\text { Sephadex } \\
\text { G-75 fraction }\end{array}$ & 19541.27 & 26.23 & 745.00 & 41.78 & 24.39 \\
\hline
\end{tabular}

was discarded. Ammonium sulfate (w) was then added to the supernatant to achieve $80 \%$ saturation, incubated at $4^{\circ} \mathrm{C}$ for 24 hours, and centrifuged at $8200 \mathrm{~g}$ for 10 minutes, whereupon the precipitate was resuspended in $15 \mathrm{~mL}$ lactate buffer (pH 3.0). This enzyme solution was lyophilized and resuspended in $8 \mathrm{~mL}$ lactate buffer $(\mathrm{pH} 3.0)$ post dialysis. The resulting sample was loaded onto Sephadex G-75 medium, which was equilibrated with citrate $(\mathrm{pH}$ 5.0) and then eluted with the same buffer at a flow rate of 3-6 mL/minute. Fractions with acidic protease activity were lyophilized and subjected to the following assays.

Enzyme activity assay: Enzyme activity was determined by the conventional folin phenol method as described by Lowry et al. [21]. One unit of enzyme activity was registered upon the release of $1 \mu \mathrm{g}$ of tyrosine - resulting from the hydrolysis of casein - within 1 minute at $50^{\circ} \mathrm{C}$ and $\mathrm{pH} 2.5$.

Sodium Dodecyl Sulfate-Polyacrylamide Gel Electrophoresis (SDS-PAGE): The purified enzyme was dissolved in distilled water. $15 \mu \mathrm{L}$ of sample and $15 \mu \mathrm{L}$ of standard protein were mixed, loaded onto a $12.5 \%$ acrylamide gel, and resolved with SDS-PAGE according to the method described by Weber and Osborn [22]. Gels were stained with Coomassie Brilliant Blue R-250, and the molecular weight of the acidic protease was determined relative to the standards.

Effects of $\mathrm{pH}$ and temperature on acidic protease activity and stability: Enzyme and substrate were suspended in serial lactate buffer dilutions ( $\mathrm{pH}$ 1.5-5.5), mixed, and incubated at $40^{\circ} \mathrm{C}$ for 10 minutes, whereupon the enzyme activity was measured. Enzyme activity at various $\mathrm{pH}$ values was calculated relative to the highest enzyme activity. Subsequently, the serial $\mathrm{pH}$ enzyme solutions were incubated at room temperature for 24 hours, and the residual activity and $\mathrm{pH}$ stable range of enzyme were determined. To ascertain the effect of temperature on enzyme activity, the enzyme and substrate were suspended in lactate buffer ( $\mathrm{pH} 2.5)$, and the activity of acidic protease was measured at various temperatures (30$70^{\circ} \mathrm{C}$ ) relative to the highest enzyme activity. To measure thermostability, the acidic protease-lactate buffer suspension was incubated at various temperatures $\left(30-70^{\circ} \mathrm{C}\right)$ for various durations (30-120 minutes). At discreet time intervals, the enzyme solution was cooled down immediately for 5 minutes in ice-cold water. Enzyme activity was calculated relative to the activity recorded following two minutes incubation at each temperature $\left(30-70^{\circ} \mathrm{C}\right)$.

Effect of metal ions: Various metals $\left(\mathrm{Na}^{+}, \mathrm{K}^{+}, \mathrm{Mn}^{2+}\right.$, $\mathrm{Zn}^{2+}, \mathrm{Mg}^{2+}, \mathrm{Ca}^{2+}, \mathrm{Fe}^{2+}, \mathrm{Cu}^{2+}$, and $\left.\mathrm{Li}^{2+}\right)$ were suspended in lactate buffer ( $\mathrm{pH}$ 2.5), and were added to the purified acidic protease for a final concentration of $5 \mathrm{mM}$. The samples were allowed to stand for 30 minutes and subsequently incubated for 10 minutes at $50^{\circ} \mathrm{C}$, whereupon the relative residual activity was measured.

\section{RESULTS AND DISSCUSION}

ITS analysis and morphology: ITS sequence of RN-11 strain was deposited in GenBank (accession No. HM212636). The RN-11 strain had white thick mycelium with black sporangium that had spread to the entire surface of the medium to form large colonies. The RN-11 strain was identified as Rhizopus stolonifer by manual and molecular identification.

Purification of acidic protease: The acidic protease was purified for electrophoretical homogeneity by ammonium sulfate precipitation, dialysis, and Sephadex G-75 gel filtration. The acidic protease was purified 41.8 -fold and the recovery yielded $24.4 \%$ after Sephadex G-75 chromatography (Table 1). Acidic proteases of varying molecular weights were previously isolated from bacteria, including an aspartate protease from Phycomyces blakesleeanu (35 kDa) [23], aspartate protease from Rhizopus oryzae (34 $\mathrm{kDa}$ [11] and $47.5 \mathrm{kDa}$ [24] variants), protease $\mathrm{A}(37 \mathrm{kDa})$ and protease $\mathrm{B}$ (34 kDa) from Aspergillus niger [25], Aspartic protease Sapt1p (44 kDa), Sapt2p (49 kDa), Sapt3 (55 kDa proproitein and $48 \mathrm{kDa}$ mature protein) [10], and two forms of acid protease (M1 $150 \mathrm{kDa}$ and M2 $60 \mathrm{kDa}$ ) from Aspergillus oryzae [26]. Unlike previously reported data, the purified acidic protease in this study was a monomer with an MW of $\sim 70 \mathrm{kDa}$ according to SDS-PAGE analysis (Fig. 1). The greater MW observed in the present study may be speciesspecific.

Effects of $\mathrm{pH}$ and temperature: The purified protease was stable at $\mathrm{pH} 2.0-3.0$ and exhibited maximal activity at $\mathrm{pH} 2.5$ (Fig. 2). Furthermore, $\geq 70 \%$ activity remained after 24 hours of incubation at room temperature at $\mathrm{pH}$ ranges of 2.0-4.0, in conformity with the results reported by Li [27], Jose [23], Eneyslaya [28], Yin [24], and Chen [25]. According to the studies conducted by Hsiao [29], Kumar [11], Li [33] and Xu [35], the optimal $\mathrm{pH}$ values of extracellular acid protease from Rhizopus oryzae, and Aspergillus spp. were 3.4, 5.5, 3.5 , and 4.0 , respectively. From the data obtained in this study, the optimal $\mathrm{pH}$ for the hydrolysis of casein was 2.5 (Fig. 3), which was markedly lower than that of acidic proteases reported elsewhere. 


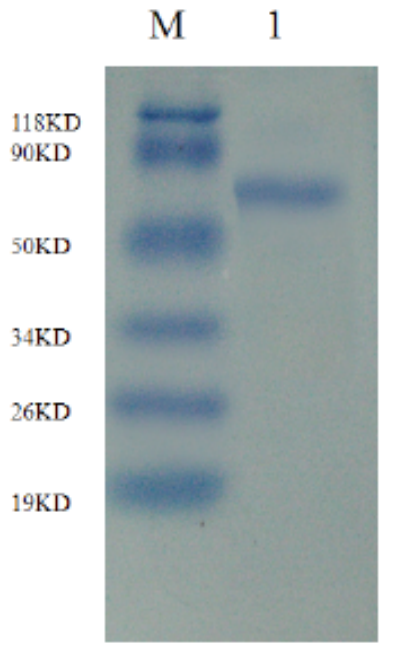

Fig. (1). SDS-PAGE of purified acidic protease from $R$. stolonifer RN-11 strain. The enzyme was resolved on a $12.5 \%$ acrylamide gel and stained with Coomassie Brilliant Blue R-250. Lane M, molecular weight markers; lane 1 , purified acidic protease $(\sim 70 \mathrm{kDa}$ molecular weight).

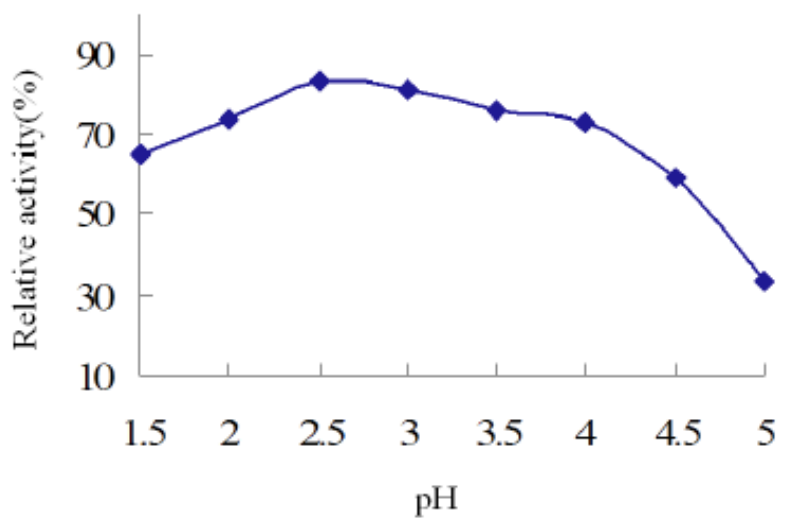

Fig. (2). $\mathrm{pH}$ stability of the purified $R$. stolonifer $\mathrm{RN}-11$ acidic protease. The relative activity was expressed as percentage relative to the highest activity (100\%).

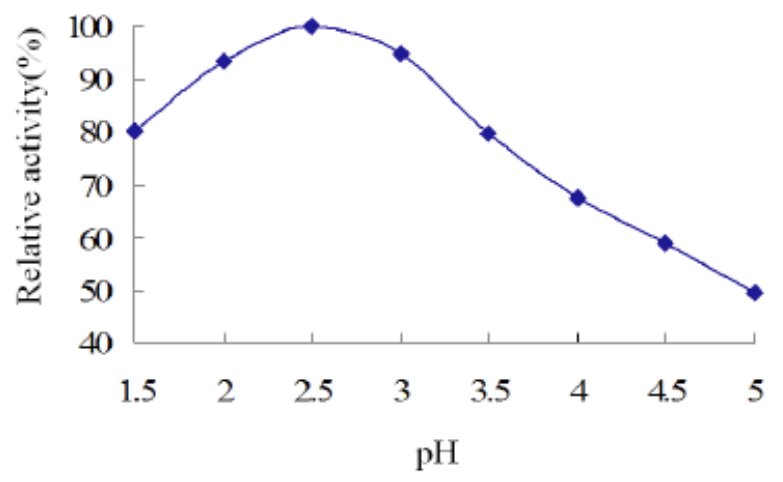

Fig. (3). Optimum $\mathrm{pH}$ of the purified $R$. stolonifer $\mathrm{RN}-11$ acidic protease. The relative activity was expressed as percentage relative to the highest activity $(100 \%)$.
The purified acidic protease in the present study exhibited certain activity at various temperatures $\left(30-70^{\circ} \mathrm{C}\right)$. Relative activity within the range of $30-50^{\circ} \mathrm{C}$ increased from $60 \%$ to $100 \%$ with an increase in temperature, but rapidly declined with increasing temperature to $38.9 \%$ of its maximal at $70^{\circ} \mathrm{C}$ (Fig. 5). The optimum temperature for acid protease activity was $50^{\circ} \mathrm{C}$ (Figs. 4 and 5). This was similar to the rhizopuspepsin from Rhizopus oryzae NBRC 4749 [25] and acid protease from Aspergillus foetidus [34], but lower than that of rhizopuspepsins $\left(60^{\circ} \mathrm{C}\right)$ from $R$. chinensis Saito [14] and R. oryzae MTCC 3690 [11].

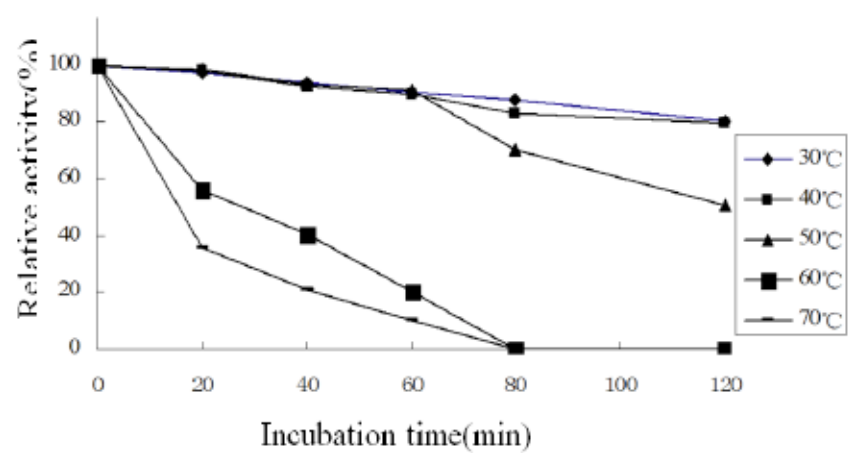

Fig. (4). Thermostability of the purified $R$. stolonifer $\mathrm{RN}-11$ acidic protease. The relative activity was expressed as percentage relative to the highest activity $(100 \%)$.

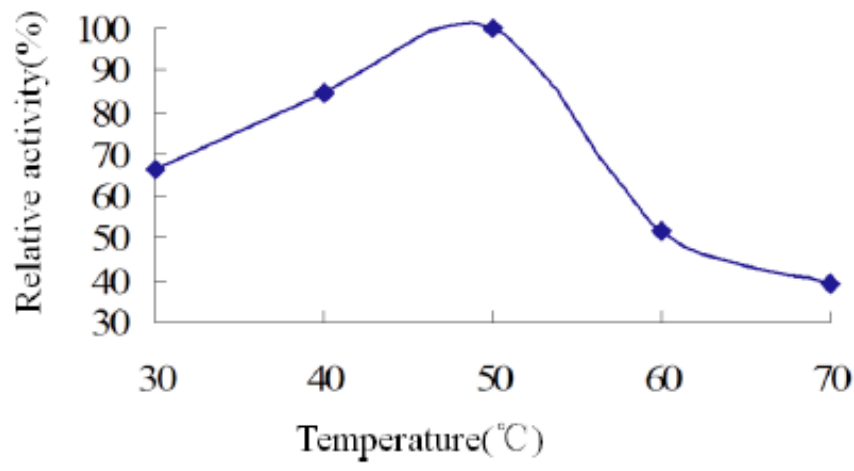

Fig. (5). Optimum temperature of the purified $R$. stolonifer $\mathrm{RN}-11$ acidic protease. The relative activity was expressed as percentage relative to the highest activity $(100 \%)$.

The purified acidic protease was stable within the range of $30-50^{\circ} \mathrm{C}$, but unstable at temperatures $>50^{\circ} \mathrm{C}$ (Fig. 5). At $30-40^{\circ} \mathrm{C}$, the enzyme showed maximal activity at $>90 \%$ after 120 minutes of incubation. At $50^{\circ} \mathrm{C}$, enzyme activity decreased slowly to $\sim 90 \%$ after 60 minutes of incubation; at $60^{\circ} \mathrm{C}$ and $70^{\circ} \mathrm{C}$, enzyme activity declined sharply to $55.7 \%$ and $35.6 \%$ after only 20 minutes of incubation, respectively. The observed half-life for the protease was approximately 120 minutes at $50^{\circ} \mathrm{C}$. The thermostability of acidic proteases highly varied within the Rhizopus oryzae $\left(30-45^{\circ} \mathrm{C}\right)$ [11], Aspergillus oryzae MTCC $5341\left(40-57^{\circ} \mathrm{C}\right)[30]$, A. niger I1 $\left(30-40^{\circ} \mathrm{C}\right)$ [3], and Mucor pilosus $\left(25-55^{\circ} \mathrm{C}\right)$ [31] species. Rhizopuspepsin from $R$. oryzae MTCC 3690 had a half-life of $\sim 20$ minutes at $60^{\circ} \mathrm{C}$, and retained full activity after 


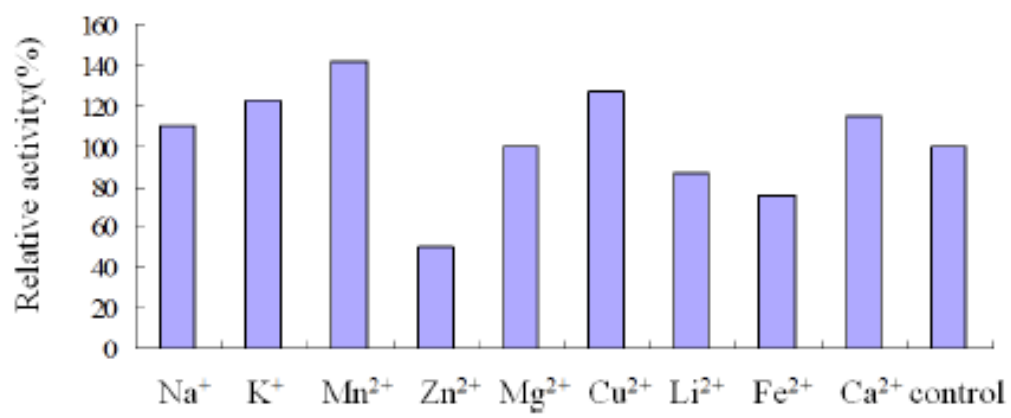

Fig. (6). Effect of metal ion on $R$. stolonifer $\mathrm{RN}-11$ acidic protease activity. The relative activity was expressed as percentage relative to the control (activity of acidic protease in the absence of metal ions).

incubation at $40^{\circ} \mathrm{C}$ for 1 hour [11]. Moreover, Chen et al. reported that rhizopuspepsin 6 from $R$. oryzae NBRC 4749 had half-lives of 210 and 10 minutes following incubation at 40 and $60^{\circ} \mathrm{C}$, respectively, [17]. These results, in conformity with the results of the study conducted by Hsiao et al. [29], suggest that aspartic proteases from Rhizopus species are stable at temperatures below $50^{\circ} \mathrm{C}$ and are prone to inactivation at greater temperatures.

Effect of metal ions: The addition of $5 \mathrm{mM} \mathrm{Na}^{+}, \mathrm{K}^{+}, \mathrm{Mn}^{2}$, $\mathrm{Cu}^{2+}$, or $\mathrm{Ca}^{2+}$ improved enzyme activity $<10 \%$, whereas $\mathrm{Mn}^{+}$improved enzyme activity by $40 \%$. The addition of $5 \mathrm{mM} \mathrm{Mg}{ }^{2+}$ had no effect on proteolytic activity, while the addition of $5 \mathrm{mM} \mathrm{Zn}{ }^{2+}, \mathrm{Li}^{2+}$, or $\mathrm{Fe}^{2+}$ reduced enzyme activity (Fig. 6). $\mathrm{Ca}^{2+}$ was a potent activator [29] [32], causing a 2.5fold increase in milk clotting activity compared to a negative control. $\mathrm{Mg}^{2+}$ and $\mathrm{Mn}^{2+}$ also had stimulatory effects [11], which were also observed in the present study. Some metal ions seemed to have various effects on the activity of acidic proteases from different fungi. Rhizopuspepsin from Rhizopus chinensis, for example, was strongly inhibited by $\mathrm{Fe}^{3+}$, but unaffected by $\mathrm{Cu}^{2+}, \mathrm{Hg}^{2+}, \mathrm{Fe}^{2+}$, and $\mathrm{Pb}^{2+}$ [14]. Meanwhile, $\mathrm{Fe}^{2+}$ is a potent activator of the acidic protease from Aspergillus niger BCRC 32720, whereas $\mathrm{Fe}^{3+}, \mathrm{Cr}^{3+}, \mathrm{Sb}^{3+}$, $\mathrm{Pb}^{2+}, \mathrm{Sn}^{2+}, \mathrm{Sr}^{2+}$, and $\mathrm{Ag}^{+}$were potent inhibitors [24]. $\mathrm{Cu}^{2+}$ strongly inhibited the acidic protease from $A$. niger [3].

In conclusion, the acid protease isolated from Rhizopus stolonifera $\mathrm{RN}-11$ was purified with a $24.4 \%$ recovery yield, and was characterised with an optimal $\mathrm{pH}$ of 2.5 and was stable below $50^{\circ} \mathrm{C}$.

\section{CONFLICT OF INTEREST}

The authors confirm that this article content has no conflict of interest.

\section{ACKNOWLEDGEMENTS}

This work is supported by Natural Science Research Project of Henan Province (No. 132300410350).

\section{REFERENCES}

Barrett AJ, Rawlings ND, Woessner JF. Handbook of proteolytic enzymes. E-STREAMS: Electronic reviews of Science and Technology USA: Elsevier 2005.

[2] Singh A, Ghosh V, Ghosh P. Production of thermostable acid protease by Aspergillus niger. Lett. Appl. Microbiol. 1994, 18: 177180.
[3] Siala R, Sellami-Kamoun A, Hajji M, Abid I, Gharsallah N, Nasri M. Extracellular acid protease from Aspergillus niger II: purification and characterization. Afr. J. Biotechnol. 2009, 8: 4582-4589.

[4] Narahara H, Koyama Y, Yoshida T, Pichangkura S, Ueda R, Taguchi $\mathrm{H}$. Growth and enzyme production in a solid-state culture of Aspergillus oryzae. J. Ferment. Technol. 1982, 60: 311-319.

[5] Narahara H, Koyama Y, Yoshida T, Poonsuk A, Taguchi H. Control of water content in a solid state culture of Aspergillus oryzae. J.Ferment. Technol. 1984, 62: 453-459.

[6] Numokawa Y. Purification of two acid-proteases of Aspergillus oryzae from takadiastase. Agric. Biol. Chem. 1965, 29: 687-692.

[7] Yegin S, Fernandez-Lahore M, Gama-Salgado AJ, Guvenc U, Goksungur Y, Tari C. Aspartic proteinases from Mucor spp. in cheese manufacturing. Appl Microbiol Biotechnol. 2011, 89: 94960 .

[8] Hashimoto H, Kaneko Y, Iwaasa T, Wokotsuka T. Production and purification of acid protease from the thermophilic fungus, Penicillium duponti K1014. Appl. Microbiol. 1973, 25: 584-588.

[9] Oka T, Ishino K, Tsuzuki H, Morihara K, Arima K. On the specificity of a rennin-like enzyme from Mucor pusillus. Agri. Biol. Chem. 1973, 37: 1177-1184.

[10] Zaugg C, BorgVonZepelin M, Reichard U, Sanglard D, Monod M. Secreted aspartic proteinase family of Candida tropicalis. Infection and Immunity, 2001, 69(1): 405-412.

[11] Kumar S, Sharma NS, Saharan MR, Singh R. Extracellular acid protease from Rhizopus oryzae: purification and characterization. Process Biochem. 2005, 40: 1701-1705.

[12] Lin JS, Lee SK, Chen Y, Lin WD, Kao CH. Purification and characterization of a novel extracellular tripeptidyl peptidase from Rhizopus oligosporus. J Agric Food Chem. 2011, 59: 11330-11337.

[13] Heskamp ML, Barz W. Expression of proteases by Rhizopus specie-s during Tempeh fermentation of soybeans. Food/Nahrung, 1998, 42: 23-28.

[14] Fukumoto J, Daisuke T, Yamamoto T. Studies on mold protease. Part I: Purification, crystallization and some enzymatic properties of acid protease of Rhizopus chinensis. Agric Biol Chem. 1967, 31: 710-717.

[15] Schoen C, Reichard U, Monod M, Kratzin H, Rüchel R. Molecular cloning of an extracellular aspartic proteinase from Rhizopus microsporus and evidence for its expression during infection. Med Mycol. 2002, 40: 61-71.

[16] Ichishima E, Ojima M, Yamagata Y, Hanzawa S, Nakamura T. Molecular and enzymatic properties of an aspartic proteinase from Rhizopus hangchow. Phytochemistry. 1995, 38: 27-30.

[17] Chen CC, Cho YC, Lai CC, Hsu WH. Purification and characteriza-tion of a new rhizopuspepsin from Rhizopus oryzae NBRC 4749. J Agric Food Chem. 2009, 57: 6742-6747.

[18] Green Michael R., Sambrook Joseph. Molecular Cloning: A Laboratory Manual (3rd ed.). Cold Spring Harbor Laboratory Press, 2001, 512.

[19] Wei JC. Fungal Identification Manual. Shang-hai Scientific \& Techn-ical Publishers. 1979, 100. (in Chinese)

[20] Bradford, M. M. A rapid and sensitive method for the quantitation of microgram quantities of protein utilizing the principle of proteindye binding. Analyt. Biochem. 72: 248-254.

[21] Lowry $\mathrm{OH}$, Rosenrough N, Farr AL, et al. Proteinmeasurement with the folin phenol reagent. J Biol Chem. 1951, 193: 265-75. 
[22] Weber K, Osborn M. The reliability of molecular weight determinations by dodecyl sulfate-polyacrylamide gel electrophoresis. J Biol Chem. 1969, 244(16): 4406-4412.

[23] Jose I. De Vicente, Dolores De Arriaga, Pilar Del Valle;Joaquin Soler, Arturo P. Eslava. Purification and Characterization of an Extracellular Aspartate Protease from Phycomyces blakesleeanu. Fungal Genetics and Biology. 1996, 20(2): 115-124.

[24] Li-Jung Yin, Tzu-Hui Hsu, Shann-Tzong Jiang. Characterization of Acidic Protease from Aspergillus niger BCRC 32720. J Agric Food Chem. 2013, 61(3): 662-666.

[25] Chun-Chang Chen, Yen-Ching Cho, Chien-Chen Lai, Wen-Hwei Hsu. Purification and Characterization of a New Rhizopuspepsin from Rhizopus oryzae NBRC 4749. Journal of Agricultural and Food Chemistry. 2009, 57(15): 6742-6747.

[26] Yoshio TSUJITA, Akira ENDO. Purification and Characterization of the Two Molecular Forms of Membrane Acid Protease from Asp-ergillus oryzae. European Journal of Biochemistry. 1978, 84(2): 347-353.

[27] Li, Y. Sheep-pelt bating with acid protease. J. Am. Leather Chem. Assoc. 2001, 96: 398-400.

[28] E.V.Eneyskaya, A.A.Kulminskaya, A.N. Savelev, N.V. Saveleva, K. A. Shabalin, K. N. Neustroev. Acid protease from Trichoderma reesei: limited proteolysis of fungal carbohydrases. Applied Microbiology and Biotechnology. 1999, 52(2): 226-231.

[29] Nai-Wan Hsiao, Yeh Chen, Yi-Chia Kuan, Yen-Chung Lee, ShuoKang Lee, Hsin-Hua Chan, Chao-Hung Kao. Purification and cha- racterization of an aspartic protease from the Rhizopus oryzae protea-se extract, Peptidase R. Electronic Journal of Biotechnology. 2014, 17(2): 1-6.

[30] Vishwanatha, K. S.; Rao, A. G.; Singh, S. A. Characterisation of acid protease expressed from Aspergillus oryzae MTCC 5341. Food Chem. 2009, 114: 402-407.

[31] Lakshman P. L. N, Toyokawa Y, Toyama H, Toki T, Yasuda M. Purification and characterisation of two extracellular acid proteinases from Monascus pilosus. Food Chem. 2010, 121: 1216-1224.

[32] Preetha S, Boopathy R. Purification and characterization of a milk clotting protease from Rhizomucor miehei. World Journal of Microbiology \& Biotechnology.1997, 13(5): 573-578.

[33] Li C, Xu D, Zhao M, et al. Production optimization, purification, and characterization of a novel acid protease from a fusant by $A s$ pergillus oryzae and Aspergillus niger. European Food Research \& Technology, 2014, 238(6): 1-13

[34] Souza P M, Aliakbarian B, Filho E X F, et al. Kinetic and thermodynamic studies of a novel acid protease from Aspergillus foetidus. International Journal of Biological Macromolecules, 2015, 81: 1721.

[35] Xu D, Li C, Wang Y, et al. Characterisation of acid proteases from a fusant F76 and its progenitors Aspergillus oryzae HN3042 and Aspergillus niger CICC2377. International Journal of Food Science \& Technology, 2013, 48(4): 678-684.

Received: June 05, 2015

Revised: August 20, 2015

Accepted: September 11, 2015

(C) Liu and Huang; Licensee Bentham Open.

This is an open access articles licensed under the terms of the Creative Commons Attribution-Non-Commercial 4.0 International Public License (CC BY-NC 4.0) (https://creativecommons.org/licenses/by-nc/4.0/legalcode), which permits unrestricted, non-commercial use, distribution and reproduction in any medium, provided that the work is properly cited. 